\title{
Interannual variations in fire weather, fire extent, and synoptic-scale circulation patterns in northern California and Oregon
}

\author{
Valerie Trouet • Alan H. Taylor • Andrew M. Carleton • \\ Carl N. Skinner
}

Received: 3 September 2007 / Accepted: 4 February 2008 / Published online: 16 April 2008

(C) Springer-Verlag 2008

\begin{abstract}
The Mediterranean climate region on the west coast of the United States is characterized by wet winters and dry summers, and by high fire activity. The importance of synoptic-scale circulation patterns (ENSO, PDO, PNA) on fire-climate interactions is evident in contemporary fire data sets and in pre-Euroamerican tree-ring-based fire records. We investigated how interannual variability in two fire weather indices, the Haines index (HI) and the Energy Release Component (ERC), in the Mediterranean region of southern Oregon and northern California is related to atmospheric circulation and fire extent. Years with high and low fire weather index values corresponded to years with a high and low annual area burned, respectively. HI combines atmospheric moisture with atmospheric instability and variation in $\mathrm{HI}$ was more strongly associated with interannual variation in wildfire extent than ERC, which is based on moisture alone. The association between fire extent and $\mathrm{HI}$ was also higher for fires in southern Oregon than in northern California. In terms of synoptic-scale circulation patterns, years of high fire risk (i.e., increased potential for erratic fire behavior, represented by HI and ERC) were associated with positive
\end{abstract}

\footnotetext{
V. Trouet $(\bowtie)$

Zürcherstrasse 111,

8903 Birmensdorf, Switzerland

e-mail: valerie.trouet@wsl.ch

\author{
A. H. Taylor · A. M. Carleton \\ The Pennsylvania State University, \\ University Park, PA, USA \\ C. N. Skinner \\ Pacific Southwest Research Station, \\ Redding, CA, USA
}

Swiss Federal Research Institute WSL, Dendrosciences, winter PNA and PDO conditions, characterized by enhanced regional mid-tropospheric ridging and low atmospheric moisture. The time lag we found between fire risk potential and prior winter circulation patterns could contribute to the development of long-lead fire-climate forecasting.

\section{Introduction}

Wildland forest fires pose a significant threat to life and property in the Mediterranean climate region of the United States (U.S.), which is characterized by cool, moist winters and warm, dry summers, which promote conditions supporting vegetation fires in most ecosystems annually. This is illustrated by the history of large and severe wildfires in the region (Biswell 1989; Skinner and Chang 1996). Climate has a strong but complex influence on fire occurrence and extent because it controls vegetation (fuels), and fire activity varies over a range of temporal and spatial scales. For example, short-term (hourly to daily) variations in fire weather variables (i.e., relative humidity, precipitation, temperature, wind velocity) affect local fire behavior (Flannigan and Harrington 1988; Bessie and Johnson 1995), whereas seasonal and interannual variations in precipitation and temperature, which in turn are affected by synoptic-scale circulation patterns, influence rates of fuel production and the flammability of live and dead fuels over wide areas (Swetnam and Betancourt 1998; Trouet et al. 2006). On time scales of decades to centuries, climatic change influences fire regimes by controlling vegetation composition and structure and, hence, fuel types and loads (Swetnam 1993).

The importance of synoptic-scale circulation patterns, such as El Niño Southern Oscillation (ENSO), the Pacific 
Decadal Oscillation (PDO), and the Pacific/North American (PNA) pattern, on fire-climate in the western U.S. is evident in both contemporary records of fire occurrence and extent (Westerling and Swetnam 2003; Gedalof et al. 2005; Trouet et al. 2006) and pre-EuroAmerican tree ring data (Swetnam and Betancourt 1990, 1998; Heyerdahl et al. 2002; Hessl et al. 2004; Taylor and Beaty 2005). ENSO, and the PNA pattern with which it can be associated (e.g., Carleton et al. 1990; Leathers et al. 1991), is a significant source of interannual climatic variability in the Pacific coast states. On decadal time-scales, climate variability is coupled more closely with the PDO (Mantua et al. 1997; Gershunov et al. 1999), which can modulate the influence of ENSO either constructively (i.e., in the same sense) or destructively (opposing one another) (Gershunov and Barnett 1998; McCabe and Dettinger 1999; Brown and Comrie 2004).

Both the ENSO teleconnection and the PDO are generally expressed as a north-south dipole climate pattern in the western U.S. (Dettinger et al. 1998). In the Pacific Northwest (PNW), comprising the coastal areas of Washington and Oregon, anomalously warm and dry conditions during the winter months are characteristic of the positive (i.e., warm) phase of ENSO (El Niño) and/or PDO, whereas the Southwest (SW), comprising Southern California, shows wet anomalies during the same phase (Andrade and Sellers 1988). The opposite spatial pattern of climatic conditions prevails during the cool ENSO (La Niña)/PDO phases. The pivotal latitude of the dipole is located ca. 40 $45^{\circ} \mathrm{N}$, but shifts south or north on interannual and decadal time-scales (Dettinger et al. 1998).

Another important synoptic-scale circulation pattern influencing the western U.S., which is likely to influence fire activity, is the PNA. The PNA is a function of the preferred locations and amplitudes of the mid-tropospheric wave train over the North Pacific and North America sectors (Wallace and Gutzler 1981). In the positive mode of the PNA (PPNA), the ridge over western North America is enhanced, along with the troughs over the North Pacific and eastern North America. The anomalously strong ridge over western North America deflects moisture-bearing cyclonic systems from the Pacific producing a more meridional flow over the North American continent. In the reverse mode of PNA (RPNA), the time-averaged ridge over the western U.S. is weakened, becoming a relative trough in the height anomaly field (Leathers et al. 1991). Whereas dry and warm winter conditions prevail in the western U.S. during the PPNA phase, the RPNA phase is characterized by wet and cold anomalies (Leathers et al. 1991).

Despite considerable research into understanding the relationship between drivers of interannual climatic variability and fire occurrence and extent (e.g., Swetnam and Betancourt 1990, 1998; Westerling and Swetnam 2003; Trouet et al. 2006), little research has focused on the effect of these drivers on interannual variability of fire weather conditions (and the associated fire risk), or on the synopticscale circulation patterns associated with these variations (e.g., Verdon et al. 2004). Fire weather indices are used by fire managers to measure meteorological conditions that influence the spread and intensity of fire and to assess fire danger. Several observational studies have examined the relationship between wildfire activity and meteorological conditions for specific fires and/or over limited geographic areas (Brotak 1993; Saltenberger and Barker 1993; Werth and Ochoa 1993; Garcia Diez et al. 1994, 1999; Potter 1996). The average annual frequency and the seasonal variability in high or low values of fire weather indices have also been examined for specific regions in the U.S. (Werth and Werth 1998; Winkler et al. 2007), but these studies did not analyze interannual indices variability or relate variability to synoptic-scale circulation patterns.

Given the lack of research on the influence of synopticscale circulation patterns on fire weather conditions on the American west coast, our study is aimed at determining how interannual variability in surface fire weather is related to variation in dominant modes of synoptic-scale circulation (i.e., ENSO, PDO, PNA), secondary atmospheric features (comprising the synoptic circulation pressure centers of action), and fire extent, in northern California and southern Oregon. This region was chosen for analysis because it has a history of large wildfires and straddles the pivotal latitude of the ENSO-PDO dipole, where fires appear to be synchronized with those in PNW in some decades and with the SW in others (Taylor and Beaty 2005).

We used the lower atmospheric index developed by Haines (1988) and the Energy Release Component (ERC) as our fire weather indices. The Haines index (HI) combines lower atmospheric components of stability and moisture into a measure of potential for erratic fire behavior, potential wildfire growth, and fire risk. Atmospheric instability is an important factor in fire growth via its enhancement of uplift, fire spotting (the lofting of burning material that ultimately drops outside the fire line, resulting in new fires), and convective surface winds. Thus, HI provides a measure of fire weather conditions for plumedominated wildfires, for which a convective plume is more important for fire growth than horizontal wind (Werth and Ochoa 1993). ERC, on the other hand, is only a composite index of fuel moisture, and it is calculated as an output of the National Fire Danger Rating System (NFDRS). ERC is related to the available energy per unit area in the flaming front, and it reflects the contribution of fuels and fuel moisture to potential fire intensity. ERC is therefore used as an indicator of intermediate and long-term drying of fuels during the fire season (Bradshaw et al. 1983). Both indices provide a measure of fire growth potential (and thus fire danger), but are calculated independently. 
Specifically, this research addresses the following questions: (1) What is the relationship between inter-annual variation in HI and ERC and area burned?; and (2) To what extent is interannual variability in HI and ERC associated with the dominant modes of synoptic-scale circulation (PNA, ENSO, PDO) that affect the Mediterranean climate region of the U.S. west coast?

\section{Data and analysis}

\subsection{Haines index and ERC}

We used a 40-year (1961-2000) record of the HI for North America (Winkler et al. 2007) that is derived from NCEP/ NCAR reanalysis data having a spatial resolution of $2.5^{\circ}$ by $2.5^{\circ}$ (Kalnay et al. 1996). HI is defined as

$H I=a\left(T_{p 1}-T_{p 2}\right)+b\left(T_{p}-T_{d p}\right)$

where $T$ is the temperature $\left({ }^{\circ} \mathrm{C}\right)$ at two pressure surfaces in the lower and middle troposphere ( 1 and $\mathrm{p} 2)$, and $T_{\mathrm{p}}$ and $T_{\mathrm{dp}}$ are the temperature $\left({ }^{\circ} \mathrm{C}\right)$ and dew-point temperature $\left({ }^{\circ} \mathrm{C}\right)$ at the higher pressure level (lower pressure level for the 'low-elevation' variant). Given the mountainous terrain in the study area, we selected the 'high-elevation' variant of the HI, which is based on the 700-500 $\mathrm{hPa}$ (approx. 3,050-
$5,500 \mathrm{~m})$ temperature difference and the temperaturedewpoint temperature difference at $700 \mathrm{hPa}(3,050 \mathrm{~m})$, and which is recommended for the topography of the western U.S. (Haines 1988). Integer values of 1, 2, or 3 are assigned to $\mathrm{a}$ and $\mathrm{b}$ in Eq. (1) based on the temperature lapse rates and dew-point temperatures for which elevationspecific thresholds are defined. The two integers are added to produce an index that varies from 2 (low fire growth potential) to 6 (high fire growth potential). We selected HI data for nine grid points that include the study area (Fig. 1). Daily HI at each grid point was calculated for 0000 UTC (1600 Pacific Standard Time), during or just after the most active burning period of the day for fires in the western U.S. (Werth and Werth 1998). Seasonal (Winter (Jan-Mar), Spring (Apr-Jun), Summer (Jul-Sep), Fall (Oct-Dec), fire season (May-Sep)) and annual (October to September) averages of $\mathrm{HI}$ were calculated for each grid point using daily data. We also calculated the number of days with high fire risk $(\mathrm{HI} \geq 5)$ or low fire risk $(\mathrm{HI} \leq 3)$ for each season and each year.

To determine the presence of spatial variability in the interannual HI patterns among grid points that might characterize the associations between fire and synoptic-scale circulation patterns, we performed a rotated Principal Component Analysis (PCA; Richman 1986) on each HI variable. The first PCA axis explained between 70\% (spring) and 77\%
Fig. 1 Map of the study region, including two groups of $\mathrm{NF}$ (SOM3, SOM8) with similar temporal patterns of area burned (Trouet et al. 2006), nine grid points with instrumental Haines Index (HI) data (Winkler et al. 2007), and Remote Automatic Weather Stations (RAWS) in northern California $(n=19)$ and Oregon $(n=14)$ used to calculate ERC

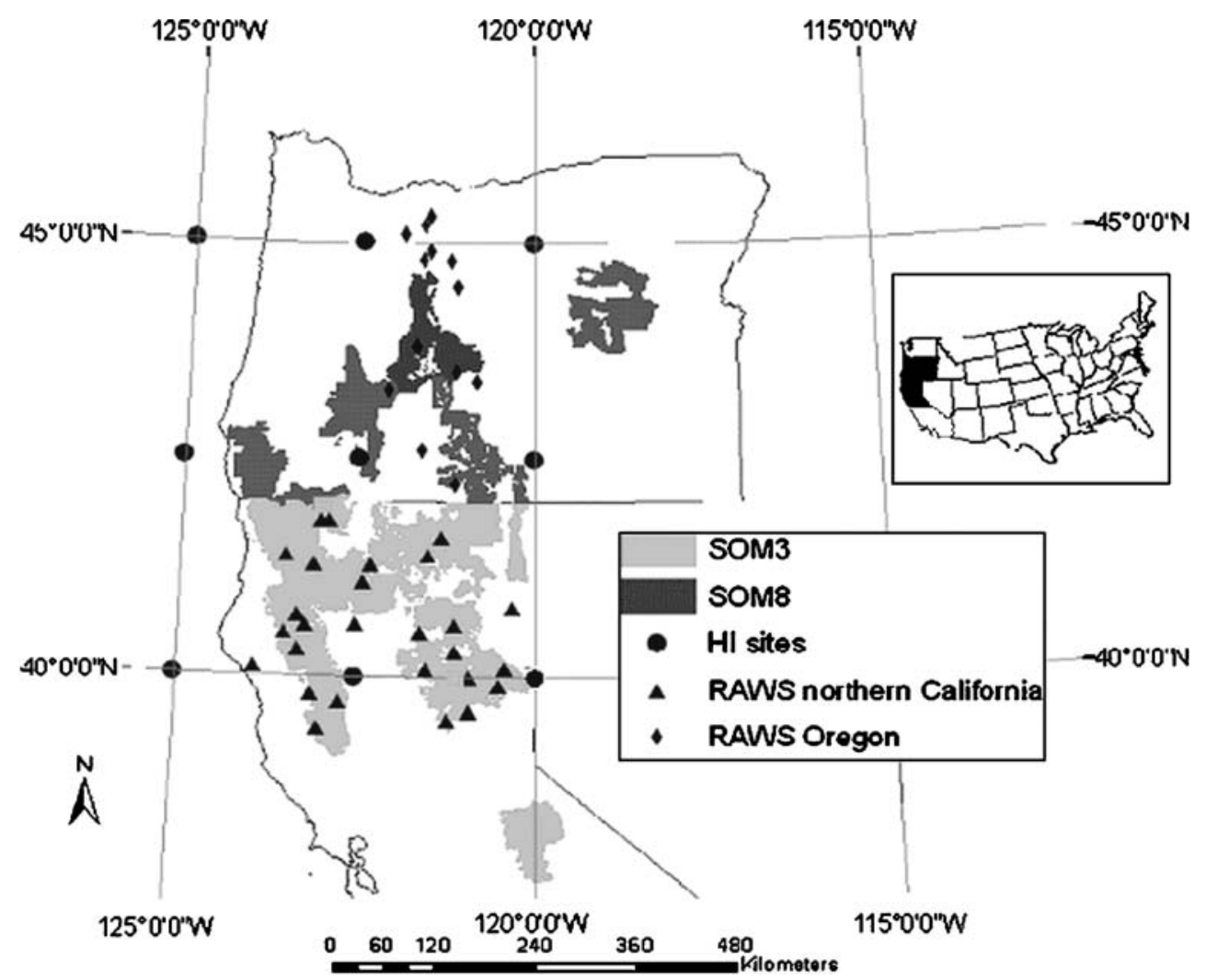


(summer) of the total variance in interannual HI, suggesting a strong common control on variance in $\mathrm{HI}$ among grid points (Fig. 2). Consequently, we used an average for all the grid points to calculate HI variables for our analyses. Zscores were calculated for each grid point before averaging to account for any spatial differences in the magnitude of each HI variable among grid points.

ERC was calculated from daily Remote Automatic Weather Stations (RAWS; Warren and Vance 1981) data and fuels data using Fire Family Plus, a fire behavior modeling software package (Main et al. 1990; Bradshaw and McCormick 2000). Daily ERC values were calculated for 19 RAWS in northern California and 14 in Oregon (Fig. 1). RAWS were chosen based on proximity to the National Forest (NF) groups in southern Oregon and northern California identified by Trouet et al. (2006) and the length of record (a minimum period of 1973-2005). The RAWS variables include 24-h precipitation, air temperature, fuel temperature, and relative humidity. We used fuel model $\mathrm{G}$ to calculate ERC for all stations. Fuel model $\mathrm{G}$ represents fuel conditions in a dense conifer stand with understory and a heavy accumulation of litter and downed woody material (Deeming et al. 1977). It is dominated by large-diameter woody fuels that are susceptible to 100 - to 1,000 -h climatic time lags of fuel moisture content. Daily variability in ERC calculated for fuel model $\mathrm{G}$ is low due to the time lag. The parameters for this fuel model are characteristic of a wide variety of western U.S. forest types and fuel model $\mathrm{G}$ is often applied for regional fire management purposes (Brown et al. 2004). Daily ERC values for the months July, August, and September were averaged to create a single (seasonal) ERC value for each year. The months of May, June, and October were not included for the seasonal calculations of average ERC, because of frequent missing values.

\subsection{Fire extent}

We used correlation analysis to identify the association between interannual variability in $\mathrm{HI}$ and ERC and annual area burned in two NF groups in southern Oregon and northern California (Fig. 1) (Trouet et al. 2006). The NF groups were identified using self-organizing maps (SOM), a non-linear, artificial neural network clustering technique (Kohonen 1989). The SOM method organizes groups by similarity of temporal patterns (Trouet et al. 2006). The temporal pattern of annual area burned in southern Oregon (SOM8) is therefore quite different from that in northern California (SOM3). SOM is sensitive to outliers (extremely large fire years), which may explain why disparate ecosystems are clustered in the same group. Because of the importance of extreme fire years with respect to fire management, we decided not to exclude extremes from the data set (Trouet et al. 2006).

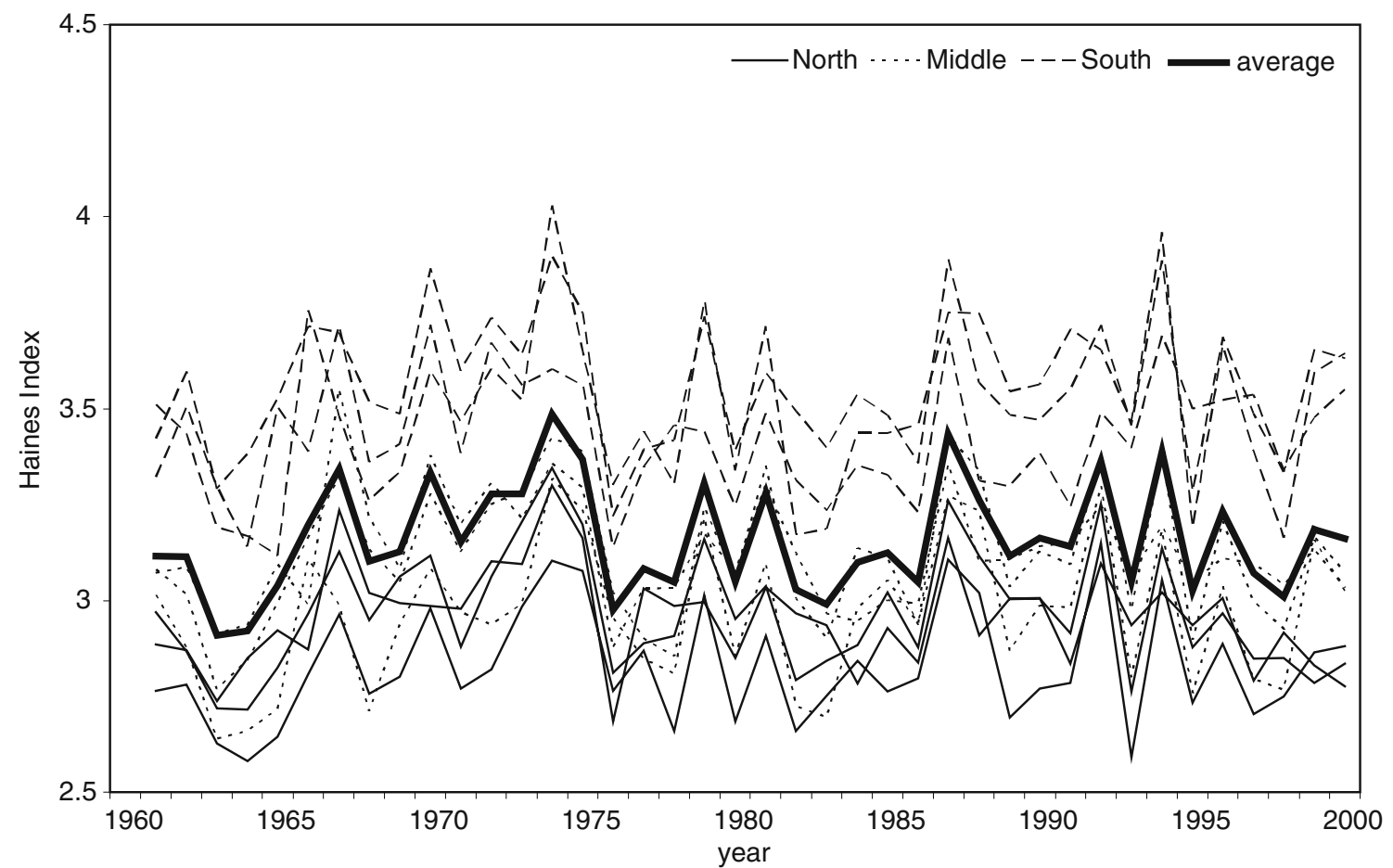

Fig. 2 Annually averaged Haines index (HI) values (1962-2000) for nine grid points in northern California and southern Oregon (see Fig. 1 for location) and their average (bold line) 
The time series of annual area burned (1929-2003) for each NF group were converted to z-scores before correlation with time series of $\mathrm{HI}$ and ERC records, to standardize for different sized NF. Additionally, first differences (value (year $\mathrm{t}$ ) - value (year $\mathrm{t}-1)$ ) of each variable were calculated, to eliminate the effect of temporal autocorrelation in the data. Correlations were calculated over the period 19612000 for HI and 1973-2003 for ERC.

\subsection{Synoptic-scale circulation patterns}

Synoptic-scale circulation patterns affect climatic variation over large spatial scales and variation in their indices may not be strongly expressed in local climate variation. We identified how ENSO, PDO, and PNA were related to climate variation in the NF fire extent groups by calculating Pearson product moment correlation coefficients between each climate index and local instrumental climate data. Correlation analysis was also used to identify the associations between circulation indices and annual and seasonal HI and ERC for each NF group.

Monthly precipitation and temperature data for 11 meteorological stations within the $40-45^{\circ} \mathrm{N} / 120-125^{\circ} \mathrm{W}$ grid (each having a minimum of 30 years of monthly data) were derived from GHCNv2 (Global Historical Climate Network version 2; Peterson and Vose 1997). Winter values were chosen because climatic teleconnections in the study region are strongest in this season, and this is also when most precipitation falls, frequently as snow. KNMI Climate Explorer (Van Oldenborgh and Burgers 2005) was used for the correlation analysis and to generate correlation maps.

The influence of synoptic-scale circulation patterns on variation in $\mathrm{HI}$ and ERC was determined using the NCEP/ NCAR reanalysis data set $\left(2.5^{\circ}\right.$ gridded measurements) of mid-tropospheric $(700 \mathrm{hPa})$ geopotential height (Kalnay et al. 1996). We calculated annual (October-September) anomalies (i.e., departures from the 1968-1996 base period) of geopotential height for each year and correlated these with the corresponding values of $\mathrm{HI}$ and ERC. For the composite map analysis, we identified the five highest and lowest years of HI and ERC, and averaged index values of three dominant modes of synoptic-scale circulation patterns (ENSO, PDO, and PNA) and geopotential height for these sets of extreme years. We used annual values of the Niño3.4 index (a measure of tropical Pacific SST variation that is frequently used as an ENSO index; Kaplan et al. 1998) and of the PDO index (Mantua et al. 1997) and monthly values of the PNA index (Wallace and Gutzler 1981). The significance of the differences in composite climatic conditions between extreme years was determined using a Student's $t$-test.

\section{Results}

\subsection{HI, ERC, and annual area burned}

Long-term averages (1961-2000) of the seasonal and annual HI were lowest in the three northernmost grid points and highest in the three southernmost grid points (Fig. 2). Seasonal HI averages were lowest in winter (2.62.8) and highest in summer (3-3.8) (Fig. 3). Average annual $\mathrm{HI}$ for the full record varied between 2.7 and 3.2. The average number of days with $\mathrm{HI} \geq 5$ ranged from 6 in winter to 15 in summer while the average number of days with $\mathrm{HI}$ values $\leq 3$ ranged from 49 in summer to 71 in winter (Fig. 3).

There was a positive association between variation in annual area burned and both $\mathrm{HI}$ and ERC in the two NF groups (Table 1). The correlations for average $\mathrm{HI}$ and for $\mathrm{HI} \geq 5$ were significant for both the year and for each season. Conversely, correlations were negative between annual area burned and seasonal and annual numbers of days with $\mathrm{HI} \leq 3$. Thus, annual area burned in both $\mathrm{NF}$ groups increased in years with a large number of high fire danger days, and vice versa. The correlations of annual area burned with HI were higher for the fire season and for the year than for other seasons (Table 1). The correlations
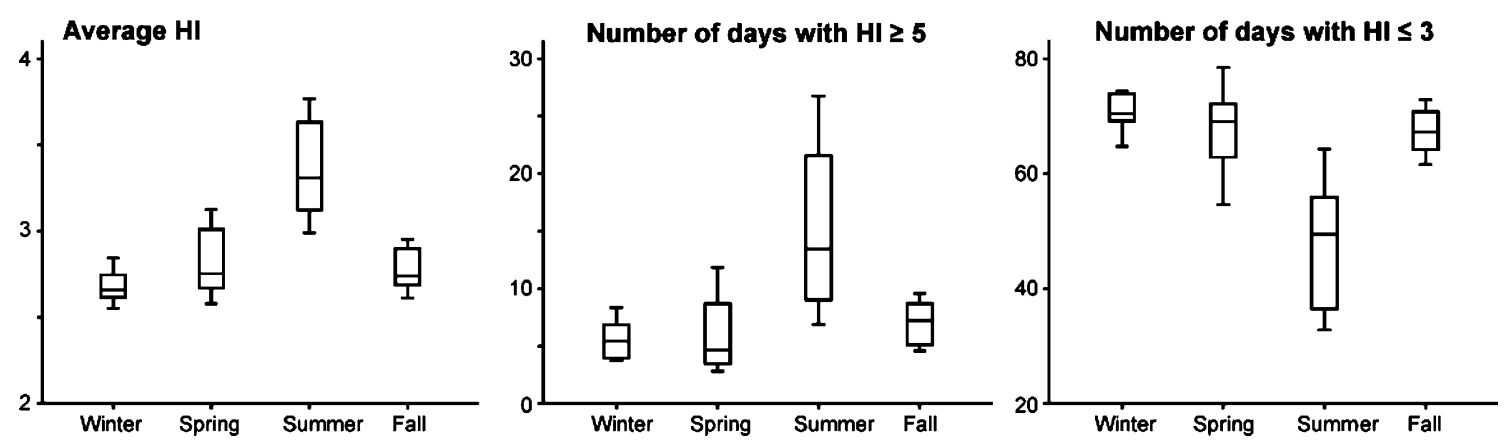

Fig. 3 Box plots for seasonal values of average HI, number of days with $\mathrm{HI} \geq 5$, and number of days with $\mathrm{HI} \leq 3$ for 9 grid points in southern Oregon and northern California 
Table 1 Correlations between seasonal and annual fire weather indices and annual area burned (AAB) in NF groups in southern Oregon (SOM3) and northern California (SOM8) (Trouet et al. 2006)

\begin{tabular}{|c|c|c|c|c|c|c|c|}
\hline & $\mathrm{AAB}$ & Annual & Winter & Spring & Summer & Fall & Fire season \\
\hline \multirow[t]{2}{*}{ HI } & Oregon & $0.58 * *$ & 0.15 & $0.46^{* *}$ & $0.39 *$ & -0.21 & $0.54 * *$ \\
\hline & California & $0.41 *$ & 0.15 & $0.36^{*}$ & $0.35^{*}$ & 0.03 & $0.41 *$ \\
\hline \multirow[t]{2}{*}{ Days $\geq 5$} & Oregon & $0.56^{* *}$ & -0.02 & $0.36^{*}$ & $0.48 * *$ & 0.01 & $0.56^{* *}$ \\
\hline & California & $0.39 *$ & 0.05 & $0.38^{*}$ & $0.35^{*}$ & 0.22 & $0.42 * *$ \\
\hline \multirow[t]{2}{*}{ Days $\leq 3$} & Oregon & $-0.6^{* *}$ & -0.15 & $-0.45^{* *}$ & $-0.39^{*}$ & 0.12 & $-0.53 * *$ \\
\hline & California & $-0.4^{*}$ & -0.14 & $-0.34 *$ & $-0.35^{*}$ & -0.06 & $-0.4^{*}$ \\
\hline \multirow[t]{2}{*}{ ERC NCA } & Oregon & & & & & & 0.34 \\
\hline & California & & & & & & $0.38^{*}$ \\
\hline \multirow[t]{2}{*}{ ERC OR } & Oregon & & & & & & $0.4^{*}$ \\
\hline & California & & & & & & 0.32 \\
\hline
\end{tabular}

$p<0.05^{*} ; p<0.01 * *$

Fire weather indices were averaged and standardized and include HI, number of days with HI values $\geq 5$, number of days with $\mathrm{HI}$ values $\leq 3$, ERC for northern California (NCA) and for Oregon (OR). HI values were calculated on a seasonal base, whereas ERC values were only available for the fire season (July-September)

between annual area burned and HI were also higher for southern Oregon than for northern California. Fire season ERC was positively correlated with annual area burned in both regions, but the correlations were lower than for HI (Fig. 4a,b).

\subsection{Teleconnection patterns}

Precipitation in the study region was generally negatively correlated with winter Niño3.4, PDOI, and PNAI values (Fig. 5a-c), while the correlations for temperature were positive (Fig. $5 \mathrm{~d}-\mathrm{f}$ ). The strength of the relationship varied among stations and between indices, indicating that the influence of dominant modes of synoptic-scale circulation was spatially explicit. ENSO had the strongest influence on winter precipitation in the region, followed by PNA. The correlations of synoptic-scale circulation patterns with precipitation were strongest in the northern part of the region (north of $42^{\circ} \mathrm{N}$ ), where the warm (i.e., positive SST anomaly) phases of ENSO, PDO, and PNA were associated with drier than normal conditions. Strong positive correlations of PNA and PDO with temperature were found throughout the region (Fig. 5e,f). No significant correlations were found between ENSO and average temperature (Fig. 5d).

As was expected, annual fire weather indices (HI, ERC $\mathrm{CA}$, and ERC OR) were negatively correlated with annual precipitation at several meteorological stations (Table 2). Annual HI was positively associated with average temperature $(\mathrm{r}=0.21$, n.s., to $\mathrm{r}=0.68, p<0.01)$, but $\mathrm{ERC}$ was not correlated with average temperature in either northern California or southern Oregon.

Variations in HI and ERC were associated with some synoptic-scale circulation patterns. Annual HI and ERC values for Oregon and California were positively correlated with winter PDOI values $(\mathrm{r}=0.47$ to $\mathrm{r}=0.52, p<0.01)$. The drier and warmer conditions occurring during positive PDO years (Fig. 5b,e) appear to promote more severe fire weather conditions. We found no significant correlations between fire weather indices and concurrent Niño3.4 values.
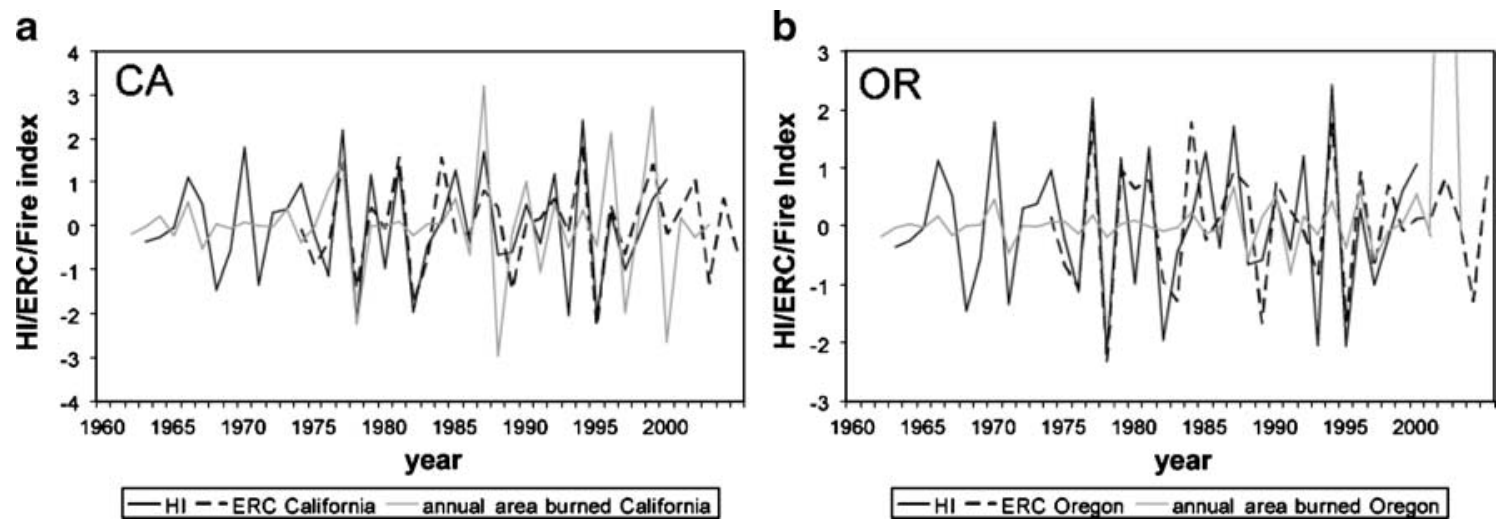

Fig. 4 Time series of the average annual Haines index (HI) and seasonal (July-September) Energy Release Component (ERC) and annual area burned in (a) northern California (SOM3) and (b) southern Oregon (SOM8). Z-scores and first differences were calculated for all data sets 


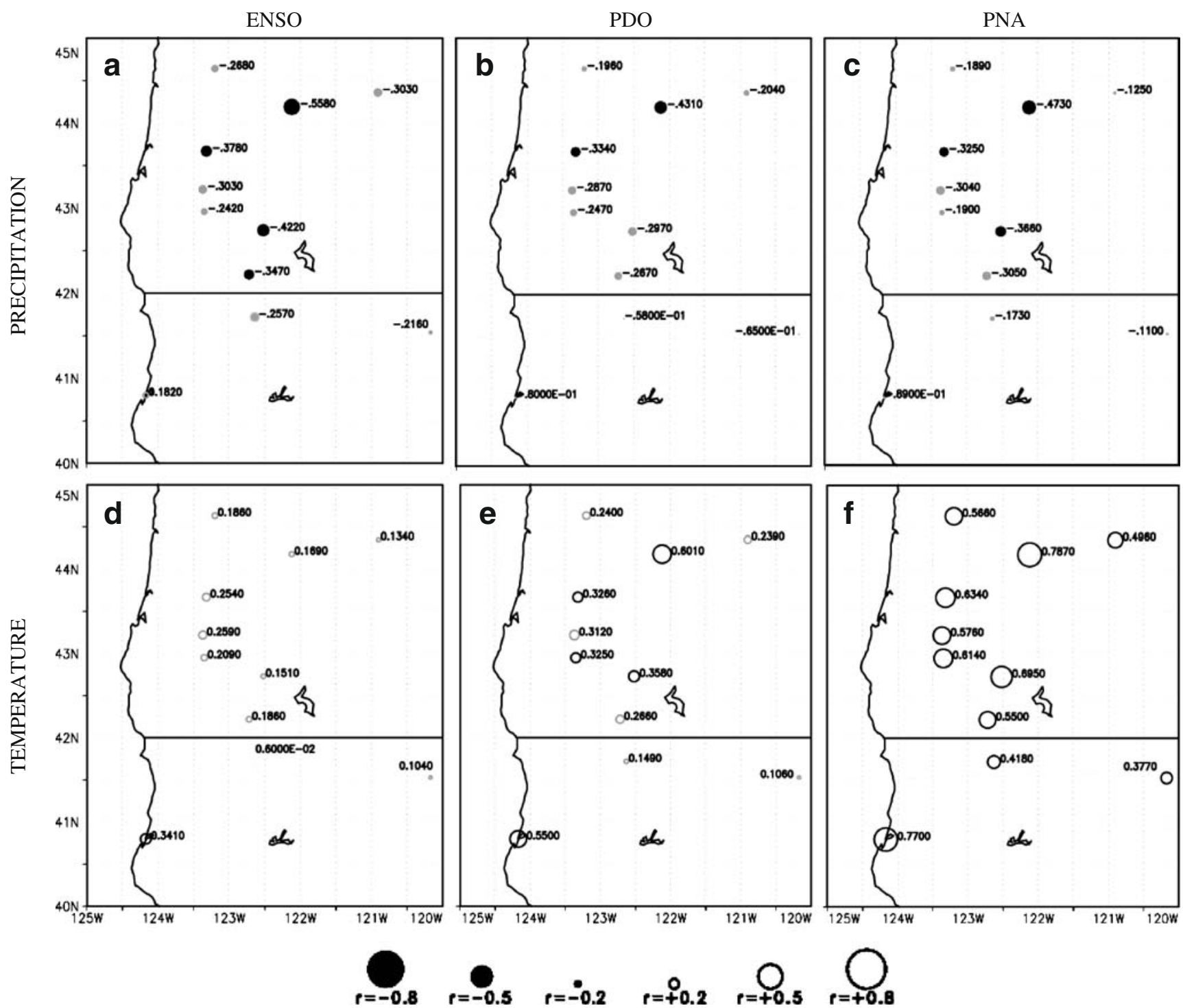

Fig. 5 Pearson correlation coefficients (1961-2000) for precipitation $(\mathbf{a}-\mathbf{c})$ and temperature $(\mathbf{d}-\mathbf{f})$ at 11 meteorological stations in northern California and southern Oregon with winter Niño3.4 (a, d), PDOI (b,

e), and PNAI (c, f). Correlation coefficients, except for those in grey graduated circles, were statistically significant $(p<0.05)$
Annual HI and monthly PNAI were also positively associated, and the correlation was strongest for December and January PNAI (Fig. 6a). Negative correlations were found for PNAI of the months of April and September (at the end of the fire season). The average PNAI for December and January explained $27 \%$ of the variance $(\mathrm{r}=$ $0.52, p<0.001$; Fig. 6b) in annual HI (1963-2000). Annual $\mathrm{HI}$ in years with a positive PNA anomaly in winter was higher than $\mathrm{HI}$ in years with a negative winter anomaly. A composite analysis of $\mathrm{HI}$ for the five highest and lowest years of winter PNAI showed that the average annual HI zscore was higher (0.44) in high PNAI years than in low PNAI years $(-0.46)(\mathrm{t}=2.37 ; p<0.05)$. The influence of PNAI on ERC was more complex. Significant correlations between PNA and ERC were found for November $(r=0.53$, $p<0.01)$ for southern Oregon, and for September $(\mathrm{r}=-0.37$, $p<0.05$ ) for northern California.

\subsection{Synoptic-scale circulation patterns}

The composite climate map analysis for years with high and low HI showed opposite anomalies of geopotential height compared to the long-term average (Fig. 7a,b). A strong PPNA mode occurred during high HI years, which is characterized by an intensification of the Continental Ridge (CR) and a deepening of the West Coast Trough (WCT) (Fig. 7a). The intensified PPNA pattern was accompanied by a northward displacement of the polar-front jetstream, a highly meridional flow in western North America, and an accordingly weakened zonal westerly flow. Consequently, 
Table 2 Location of 11 meteorological stations in California (CA) and Oregon (OR) and Pearson correlation coefficients between precipitation $(P)$ and temperature $(T)$ time series for these stations with average annual HI and average seasonal (July-September) ERC

\begin{tabular}{|c|c|c|c|c|c|c|}
\hline \multirow[t]{2}{*}{ Station } & \multirow[t]{2}{*}{ Lat./long. } & \multirow[t]{2}{*}{ Elevation (m) } & \multicolumn{2}{|l|}{$\mathrm{HI}$} & \multicolumn{2}{|l|}{ ERC } \\
\hline & & & $\mathrm{P}$ & $\mathrm{T}$ & $\mathrm{P}$ & $\mathrm{T}$ \\
\hline Eureka (CA) & $40.8 \mathrm{~N}, 124.7 \mathrm{~W}$ & 13 & $-0.58^{*}$ & 0.21 & $-0.69 *$ & 0 \\
\hline Cedarville (CA) & $41.5 \mathrm{~N}, 120.2 \mathrm{~W}$ & 1424 & $-0.56^{*}$ & $0.47 *$ & $-0.5^{*}$ & 0.26 \\
\hline Yreka $(\mathrm{CA})$ & $41.7 \mathrm{~N}, 122.6 \mathrm{~W}$ & 801 & -0.4 & 0.41 & $-0.71 *$ & 0.4 \\
\hline Ashland (OR) & $42.2 \mathrm{~N}, 122.7 \mathrm{~W}$ & 534 & $-0.55^{*}$ & $0.47 *$ & $-0.67 *$ & 0.15 \\
\hline Prospect (OR) & $42.7 \mathrm{~N}, 122.5 \mathrm{~W}$ & 757 & $-0.59 *$ & $0.65^{*}$ & $-0.6^{*}$ & 0.41 \\
\hline Riddle (OR) & $43 \mathrm{~N}, 123.4 \mathrm{~W}$ & 207 & $-0.51^{*}$ & 0.41 & $-0.63 *$ & 0 \\
\hline Roseburg (OR) & $43.2 \mathrm{~N}, 123.4 \mathrm{~W}$ & 130 & $-0.57^{*}$ & $0.6^{*}$ & $-0.68 *$ & 0.38 \\
\hline Drain (OR) & $43.7 \mathrm{~N}, 123.3 \mathrm{~W}$ & 89 & $-0.53 *$ & $0.48 *$ & $-0.6^{*}$ & 0 \\
\hline McKenzie Bridge (OR) & $44.2 \mathrm{~N}, 122.1 \mathrm{~W}$ & 451 & $-0.58^{*}$ & $0.68 *$ & $-0.68 *$ & 0 \\
\hline Prineville (OR) & $44.4 \mathrm{~N}, 120.9 \mathrm{~W}$ & 866 & $-0.49 *$ & $0.53 *$ & $-0.8^{*}$ & 0.26 \\
\hline Corvallis SU (OR) & $44.6 \mathrm{~N}, 123.2 \mathrm{~W}$ & 69 & $-0.49 *$ & 0.42 & $-0.57 *$ & 0 \\
\hline
\end{tabular}

${ }^{*} p<0.01$

moisture-bearing systems from the North Pacific were deflected north of the study region reducing precipitation and relative humidity. The increased subsidence of air in the ridge that is implied by this intensified PPNA pattern promoted increased surface temperatures, lowered humidity, and resulted in generally drier conditions (as confirmed by Fig. $5 \mathrm{c}, \mathrm{f})$. The opposite conditions characterized low HI years (Fig. 7b), when a pattern resembling the RPNA (i.e., a weakened CR and WCT) was accompanied by zonal flow and wetter than normal conditions.

Years of high and low ERC in northern California and southern Oregon showed broadly similar geopotential height patterns. High ERC years showed an intensified tropospheric ridge (Fig. 7c), which resembled the pattern in years with high HI, except that the center of the positive height anomaly was further north. Again, this pattern comprises the PPNA mode. In contrast, low ERC years were characterized by lower than normal geopotential heights (i.e., a deepened trough) over the eastern Pacific and the west coast region (Fig. 7d), yet with positive anomalies (ridging) located over northwest Canada and Alaska. This latter suite of anomalies indicates a higher-latitude blocking pattern for these longitudes; that is a reversal of the pressure/height departures from normal between middle and higher latitudes, and associated weakened westerly winds. Thus, the composite height patterns suggest that annual variation in fire weather indices is related to annual variation in synoptic-scale circulation patterns, particularly those that comprise the PNA pattern.

\section{Discussion}

Interannual variability of fire weather in the Mediterranean climate area of the U.S. west coast shows a strong regional signal, suggesting that it is influenced by atmospheric teleconnections operating through their accompanying synoptic-scale circulation patterns. Sub-regional variability (be-
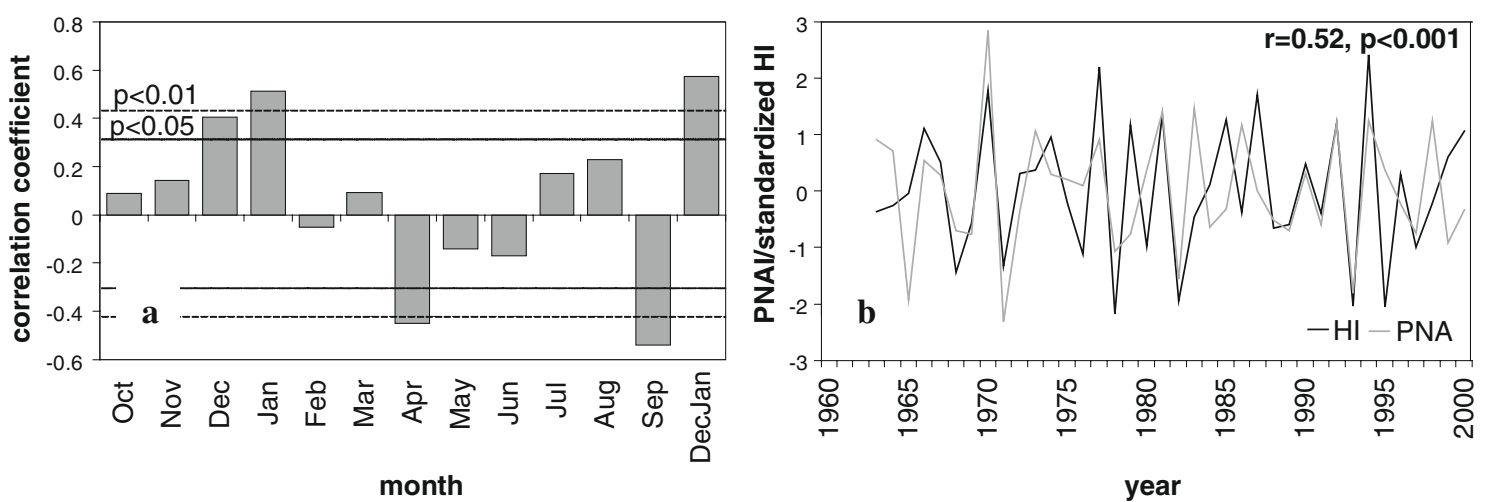

Fig. 6 a Pearson product moment correlation (1962-2000) of annual (October-September) Haines Index (HI) and average monthly PNAI. b Comparison of annual HI and PNAI (December-January). First differences were used for the analysis to emphasize inter-annual variability 

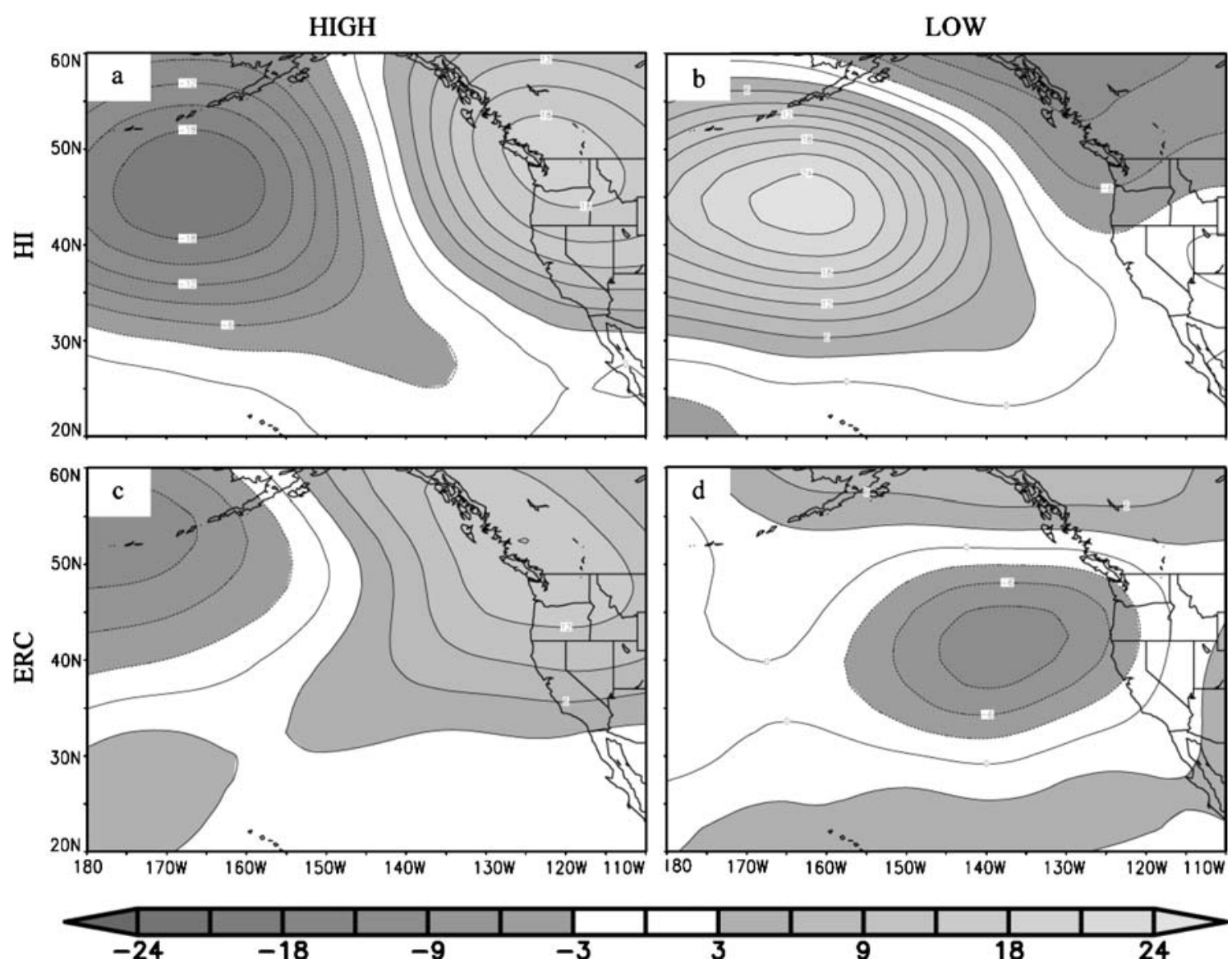

Fig. 7 Annual (October-September) $700 \mathrm{hPa}$ geopotential height anomalies for the 5 years (1962-2000) with highest and lowest annual HI values (a, b) and the 5 years (1974-2005) with highest and lowest Summer Oregon (SOM8) Energy Release Component values (ERC; c,

d). Positive anomalies (i.e., weakened trough or enhanced ridging) are indicated by light grey tones and full lines, negative anomalies (weakened ridge or enhanced troughing) by dark grey tones and dashed lines

tween grid points) of $\mathrm{HI}$ was limited to 23 to $30 \%$, depending on the season. Similar results were found for ERC time series of neighboring RAWS stations within southern Oregon and northern California. By regionally averaging the $\mathrm{HI}$ and ERC data, we emphasized the common signal.

Fire weather was generally most severe in summer (with high regional average $\mathrm{HI}$ values and high average number of days with $\mathrm{HI}$ values $\geq 5$; Fig. 3 ), when foehn-type winds in the Cascades and the Sierra Nevada result in a high frequency of days with large dew point temperature depressions (Werth and Werth 1998). Even average summer $\mathrm{HI}$ values, however, fell within the 'low' category, which is consistent with the results found by Winkler et al. (2007). On average, $17 \%$ (or approximately 1 in 6 ) of the days in summer (July to September) were characterized by high or greater than high fire risk, corresponding to the $15 \%$ found for the same region by Werth and Werth (1998), based on radiosonde data for the period 1990-1995.

The average annual (seasonal) HI and ERC reflected the number of days in a year (season) when meteorological conditions promoted high fire risk. Considering that there can be many days with high fire potential but without actual fire occurrence, a simple correlation between fire size and fire weather indices is unlikely. Additionally, there are many other factors that influence fire size (e.g., fire suppression actions, topography). Our results, however, suggest that the relation between fire potential and fire size is expressed on an interannual scale: years with a higher than normal number of high fire risk days corresponded to years with higher than normal annual area burned, and vice versa. On a seasonal level, the influence of HI was strongest in summer, when most fires occur, and weak in winter, when fire activity is usually low (Table 1). Annual area burned data represent fire activity over the full year and integrating $\mathrm{HI}$ over the same period increases strength of the association between HI and area burned.

The relationship between HI and fire extent was somewhat stronger for southern Oregon than for northern California (Table 1) and this may be related to the dominance of large fires that are ignited by lightning in northern California. The number of synchronously ignited fires can overwhelm fire-fighting forces in this area, 
especially under conditions of increased fuel accumulation characteristic of the last century (Weatherspoon and Skinner 1996). This, in addition to severe climatic conditions (as reflected by increased HI or ERC values), promotes extensive fires.

Due to its dependence on dead fuel moisture (which in turn is exclusively controlled by climatic conditions), ERC can be used as a climatic index, representing drought severity over multiple months (Bradshaw et al. 1983). The percentage of variability in annual area burned explained by ERC $(20 \%)$ for the Mediterranean climate region is comparable to the percentage explained by other drought indices, such as the Palmer Drought Severity Index (PDSI). PDSI is a composite drought index that is frequently used to identify climatic influences on fire occurrence and extent (Swetnam and Betancourt 1990; Westerling and Swetnam 2003). PDSI is a measure of soil moisture that integrates immediate and lagged precipitation and temperature in estimating drought severity (Palmer 1965). The most important atmospheric factor influencing ERC is relative humidity (Brown et al. 2004), rather than precipitation or temperature. Variations in relative humidity (as reflected by ERC), temperature, and precipitation (as reflected by PDSI) thus appear to contribute in equal amounts to interannual variations in fire extent. The percentage of annual area burned in southern Oregon explained by HI (up to 35\%, Table 1), however, is considerably greater than by ERC or by PDSI. HI includes an atmospheric stability component that can also influence rates of fire spread in the early stages of a fire and therefore fire size. Combining atmospheric instability with atmospheric moisture appears to provide a better measure of potential wildfire extent than indices based on moisture alone.

The synoptic-scale circulation conditions that induce low atmospheric stability and humidity moisture levels, and which correspond to high $\mathrm{HI}$ and ERC values (Fig. 7), also are associated with the occurrence of dry lightning days (Rorig and Ferguson 1999; Skinner et al. 2006). Thus, these atmospheric conditions not only result in enhanced fire growth potential, but also in enhanced fire ignition potential. Under these conditions, only a few days of lightning are necessary to ignite fires over large areas, which contributes to high annual area burned (Skinner et al. 2006). Pacific Coast forest fire regimes in the 20th century appear to be strongly influenced by these synoptic-scale circulation patterns, despite increasing anthropogenic influence on fire regimes, such as highly organized efforts to suppress fire, forest management that affects fuel conditions, and human-induced climate change (Agee 1993; Skinner and Chang 1996; Brown et al. 2004; Kasischke and Turetsky 2006).

Generally, large forest fires are strongly associated with synoptic-scale circulation patterns showing enhanced mid- tropospheric ridging over the affected area, accompanied by meridional flow (Johnson and Wowchuk 1993; Skinner et al. 1999, 2002; Pereira et al. 2005). This is also the case for the Mediterranean climate area on the Pacific Coast, where the enhanced trough and ridge pattern over the North Pacific and North America sectors in large fire years comprises the PPNA pattern (Trouet et al. 2006). Our results indicate that interannual variability in fire weather in the Mediterranean climate area in southern Oregon and northern California is related to synoptic-scale circulation patterns in general (Fig. 7) and the PNA pattern in particular (Fig. 6). The PPNA phase is characterized by enhanced subsidence of air in the west, resulting in low atmospheric moisture and increased temperatures over the Mediterranean climate area (Fig. 5c,f). Fire risk is higher in PPNA years and lower in RPNA years. The strongest influence of PNA on climate occurs in the winter months (Fig. 6a), when the PNA pattern is also best defined (Leathers et al. 1991). The influence of interannual variability in winter PNA was stronger for interannual variability in HI than ERC. This may be a result of the greater sensitivity of $\mathrm{HI}$ to variation in temperature in our study area (which in turn is influenced by PNA), whereas interannual variation in ERC was not related to variation in average annual temperature (Table 2).

The PDO and ENSO signatures in the $40-45^{\circ} \mathrm{N}$ pivot area over the period 1962-2000 reflect their teleconnections to the PNW. Cool PDO and La Niña phases are characterized by wetter and warmer than normal conditions, whereas conditions are reversed during warm PDO and El Niño events (Fig. 5). This pattern is more pronounced in the northern part of the region (north of $42^{\circ} \mathrm{N}$ ). Warm PDO years were associated with years of severe fire weather conditions, reflected in greater values of annual $\mathrm{HI}$ and ERC. Large fire years in this area and in the PNW previously have been linked to positive PDO conditions (Hessl et al. 2004; Gedalof et al. 2005; Trouet et al. 2006; Taylor et al., 2008).

\section{Concluding remarks}

Our analysis of the regional signal of interannual $\mathrm{HI}$ and ERC variability for nine grid points on a $2.5^{\circ}$ grid over southern Oregon and northern California confirmed that HI and ERC are measures of fire risk; that is, of the likelihood of plume-driven fires becoming large or showing erratic behavior (Winkler et al. 2007). Years with high HI and ERC were associated with widespread forest fires and particular modes of synoptic-scale circulation patterns. This work contributes to a growing pool of studies examining the effects of interannual climatic variability on wildfire activity in the western U.S. (e.g., Agee 1993; Swetnam and 
Betancourt 1998; Westerling and Swetnam 2003; Trouet et al. 2006). Our focus on interannual variation in fire weather indices may permit fire managers to more easily incorporate our results into long-term planning strategies. The 6-month time lag between fire danger potential (represented by HI and ERC) and prior winter circulation patterns (represented by PNAI and PDOI) may permit the development of longterm forecasting schemes based on atmospheric circulation (e.g., Chu et al. 2002; Kitzberger 2002). Improved understanding that can contribute to fire-climate forecasting may become more important if climatic changes driven by increased greenhouse gases, that are projected to include more intense, more frequent, and longer-lasting blocking ridges over western North America (Lupo et al. 1997; Meehl and Tebaldi 2004), begin to be expressed. These conditions are expected to increase the number of days with severe fire weather in western North America (Brown et al. 2004).

Acknowledgements This research was supported by a cooperative agreement with the USDA Forest Service, Pacific Southwest Research Station (04-JV-11272162-407) from funds provided by the USDI/ USDA Interagency Joint Fire Sciences Program and a George S. Deike Research Grant. We thank Brian Potter, Julie Winkler, and Ryan Shadbolt for providing us with the Haines index data set and for helpful suggestions about its application.

\section{References}

Agee JK (1993) Fire ecology of Pacific Northwest forests. Island Press, Washington, DC

Andrade ER, Sellers WD (1988) El Niño and its effect on precipitation in Arizona and western New Mexico. J Climatol 8:403-410

Bessie WC, Johnson EA (1995) The relative importance of fuels and weather on fire behavior in subalpine forests. Ecology 76:747-762

Biswell HH (1989) Prescribed burning in California wildland vegetation management. University of California Press, Berkeley

Bradshaw L, McCormick E (2000) FireFamily Plus user's guide, version 2.0. General Technical Report. RMRS-GTR-67WWW. Ogden, UT: USDA Forest Service, Rocky Mountain Research Station

Bradshaw LS, Deeming JE, Burgan RE, Cohen JD (1983) 1978 National Fire-Danger Rating System. Intermountain Forest and Range Experiment Station, US Department of Agriculture Forest Service Gen Tech Rep INT-169 m

Brotak EA (1993) Low-level weather preceding major wildfires. Fire Manage Notes 54:23-25

Brown DP, Comrie AC (2004) A winter precipitation 'dipole' in the western United States associated with multidecadal ENSO variability. Geophys Res Lett 31:L09203, DOI 10.1029/ 2003GL018726

Brown TJ, Hall BL, Westerling AL (2004) The impact of twenty-first century climate change on wildland fire danger in the western United States: an applications perspective. Clim Change 62:365388

Carleton AM, Carpenter DA, Weser PJ (1990) Mechanisms of interannual variability of the southwest United States summer rainfall maximum. J Clim 3:999-1015

Chu PS, Yan W, Fujioka F (2002) Fire-climate relationships and longlead seasonal wildfire prediction for Hawaii. Int $\mathrm{J}$ Wildl Fire $11: 25-31$
Deeming JE, Burgan RE, Cohen JD (1977) The National Fire-Danger Rating System - 1978. Gen. Tech. Rep. INT-39, USDA Forest Service Intermountain Forest and Range Experiment Station, pp 63

Dettinger MD, Cayan DR, Diaz HF, Meko DM (1998) North-South precipitation patterns in western North America. J Clim 11:30953111

Flannigan MD, Harrington JB (1988) A study of the relation of meteorological variables to monthly provincial area burned by wildfire in Canada 1953-80. J Appl Meteorol 27:441-452

Garcia Diez EL, Rivas Soriano L, De Pablo Davila F, Garcia Diez A (1994) An objective forecasting model for the daily outbreak of forest fires based on meteorological conditions. J Appl Met 33:519-526

Garcia Diez EL, Rivas Soriano L, De Pablo Davila F, Garcia Diez A (1999) Prediction of the daily number of forest fires. Int J Wildl Fire 9:207-211

Gedalof Z, Peterson DL, Mantua NJ (2005) Atmospheric, climatic and ecological controls on extreme wildfire years in the northwestern United States. Ecol Appl 15:154-174

Gershunov A, Barnett TP (1998) Interdecadal modulation of ENSO teleconnections. Bull Am Meteor Soc 79:2715-2725

Gershunov A, Barnett TP, Cayan DR (1999) North Pacific Interdecadal Oscillation seen as factor in ENSO-related North American climate anomalies. EOS Trans Am Geophys Union 80:25-36

Haines DA (1988) A lower atmospheric severity index for wildland fires. Natl Wea Dig 13:23-27

Hessl AE, McKenzie D, Schellhaas R (2004) Drought and Pacific decadal oscillation linked to fire occurrence in the inland Pacific Northwest. Ecol Appl 14:425-442

Heyerdahl EK, Brubaker LB, Agee JK (2002) Annual and decadal climate forcing of historical fire regimes in the Interior Pacific Northwest, USA. Holocene 12:597-604

Johnson EA, Wowchuk DR (1993) Wildfires in the southern Canadian Rocky Mountains and their relationship to mid-tropospheric anomalies. Can J For Res 23:1213-1222

Kalnay E, Kanamitsu M, Kistler R, Collins W, Deaven D, Gandin L, Iredell M, Saha GS, White JW, Zhu Y, Leetmaa A, Reynolds B, Chelliah M, Ebisuwaki W, Higgins W, Janowiak J, Mo KC, Ropelewski C, Wang J, Jenne R, Joseph D (1996) The NCEP/ NCAR 40-year reanalysis project. Bull Am Meteorol Soc $77: 437-471$

Kaplan A, Cane M, Kushnir Y, Clement A, Blumenthal M, Rajagopalan B (1998) Analyses of global sea surface temperature 1856-1991. J Geophys Res 103:18567-18589

Kasischke ES, Turetsky MR (2006) Recent changes in the fire regime across the North American boreal region-spatial and temporal patterns of burning across Canada and Alaska. Geophys Res Lett 33:L09703, DOI 10.1029/2006GL025677

Kitzberger T (2002) ENSO as a forewarning tool of regional fire occurrence in northern Patagonia, Argentina. Int $\mathrm{J}$ Wildl Fire 11:33-39

Kohonen T (1989) Self-organization and associative memory. Springer, Berlin Heidelberg New York, $\mathrm{p} 312$

Leathers DJ, Yarnal B, Palecki MA (1991) The Pacific/North American Teleconnection Pattern and United States Climate. Part I: Regional Temperature and Precipitation Associations. J Clim 4:517-528

Lupo AR, Oglesby RJ, Mokhov II (1997) Climatological features of blocking anticyclones: a study of Northern Hemisphere CCM1 model blocking events in present-day and double $\mathrm{CO}_{2}$ concentration atmosphere. Clim Dyn 13:181-195

Main WA, Paananen DM, Burgan RE (1990) Fire Family Plus. North Central Forest Experiment Station, USDA Forest Service Gen Tech Report NC-138 
Mantua NJ, Hare SR, Zhang Y, Wallace JM, Francis RC (1997) A Pacific interdecadal climate oscillation with impacts on salmon production. Bull Am Meteor Soc 78:1069-1079

McCabe GJ, Dettinger MD (1999) Decadal variations in the strength of ENSO teleconnections with precipitation in the western United States. Int J Clim 19:1399-1410

Meehl GA, Tebaldi C (2004) More intense, more frequent, and longer lasting heat waves in the 21 st century. Science 305:994997

Palmer WC (1965) Meteorological drought Research Paper 45. U.S. Dept of Commerce, Washington, DC, p 58

Pereira MG, Trigo RM, da Camara CC, Pereira JMC, Leite SM (2005) Synoptic patterns associated with large summer forest fires in Portugal. Agr For Meteor 129:11-25, DOI 10.1016/jagrformet. 2004.12.007

Peterson TC, Vose RS (1997) An overview of the Global Historical Climatology Network temperature data base. Bull Am Meteor Soc 78:2837-2849

Potter BE (1996) Atmospheric properties associated with large wildfires. Int J Wildl Fire 3:131-138

Richman MB (1986) Rotation of principal components. J Climatol 6:293-335

Rorig ML, Ferguson SA (1999) Characteristics of lightning and wildland fire ignition in the Pacific Northwest. J Appl Met 38:1565-1575

Saltenberger J, Barker T (1993) Weather related unusual fire behavior in the Awbrey Hall Fire. Natl Wea Dig 19:20-29

Skinner CN, Chang C (1996) Fire regimes, past and present. Sierra Nevada Ecosystem Project: Final Report to Congress vol. 2, Assessments and scientific basis for management options. University of California Centers for Water and Wildland Resources, Davis, CA, pp 1041-1069

Skinner WR, Stocks BJ, Martell DL, Bonsal B, Shabbar A (1999) The association between circulation anomalies in the mid-troposphere and area burned by wildland fire in Canada. Theor Appl Climatol 63:89-105

Skinner WR, Todd JB, Flannigan MD, Martell DL, Stocks BJ, Wotton BM (2002) A 500-mb synoptic wildland fire climatology from large Canadian forest fires, 1959-1996. Theor Appl Climatol 71:157-169

Skinner WR, Shabbar A, Flannigan MD, Logan K (2006) Large forest fires in Canada and the relationship to global sea surface temperatures. J Geophys Res 111:D14106, DOI 10.1029/2005JD006738
Swetnam TW (1993) Fire history and climate change in giant sequia groves. Science 262:885-889

Swetnam TW, Betancourt JL (1990) Fire-Southern Oscillation relations in the southwestern United States. Science 249:1017-1020

Swetnam TW, Betancourt JL (1998) Mesoscale disturbance and ecological response to decadal climatic variability in the American Southwest. J Clim 11:3128-3147

Taylor AH, Beaty RM (2005) Climatic influences on fire regimes in the northern Sierra Nevada Mountains, Lake Tahoe Basin, Nevada, USA. J Biogeogr 32:425-438

Taylor AH, Trouet V, Skinner CN (2008) Climatic influences on fire regimes in montane forests of the southern Cascades, California, USA. Int J Wildl Fire 17:60-71, DOI 10.1071/WF07033

Trouet V, Taylor AH, Carleton AM, Skinner CN (2006) Fire-climate interactions in forests of the American Pacific coast. Geophys Res Lett 33:L18704, DOI 10.1029/2006GL027502

Van Oldenborgh GJ, Burgers G (2005) Searching for decadal variations in ENSO precipitation teleconnections. Geophys Res Lett 32:L15701, DOI 10.1029/2005GL023110

Verdon DC, Kiem AS, Franks SW (2004) Multi-decadal variability of forest fire risk -Eastern Australia. Int J Wildl Fire 13:165-171, DOI 10.1071/WF03034

Wallace JM, Gutzler DS (1981) Teleconnections in the Geopotential Height Field during the northern hemisphere winter. Mon Wea Rev 109:784-812

Warren JR, Vance DL (1981) Remote Automatic Weather Station for Resource and Fire Management Agencies. Tech. Rep. INT-116, USDA Forest Service, Intermountain Forest and Range Experiment Station

Weatherspoon CP, Skinner CN (1996) Landscape-level strategies for forest fuel management. Sierra Nevada Ecosystem Project: Final report to Congress, Wildland Resources Center Report No. 37, Centers for Water and Wildland Resources, University of California, pp 1471-1492

Werth PA, Ochoa R (1993) The evaluation of Idaho wildfire growth using the Haines index. Wea Forecasting 8:223-234

Werth J, Werth P (1998) Haines index climatology for the western United States. Fire Manage Notes 58:8-17

Westerling A, Swetnam T (2003) Interannual to decadal drought and wildfire in the western United States. EOS 84:545-560

Winkler JA, Potter BE, Wilhelm DF, Shadbolt RP, Piromsopa K, Bian XD (2007) Climatological and statistical characteristics of the Haines index for North America. Int J Wildl Fire 16:139-152 